\title{
Analisis Nilai-Nilai Karakter Dalam Buku Cerita Rakyat Sang Piatu Menjadi Raja Dari Daerah Bengkulu
}

Ottey Zul Apriani

Universitas Bengkulu

otizulapriani17@gmail.com

\author{
Wurjinem \\ Universitas Bengkulu \\ wurjinem@gmail.com \\ Sri Ken Kustianti \\ Universitas Bengkulu \\ Srikenkustianti@gmail.com
}

\begin{abstract}
This research aims to analyse the values of characters in the folklore of the orphans to become king of the Bengkulu area the method in use is a qualitative method of descriptive analysis. The research Data is the folklore of the people who become kings. Collection with library studies. The analytical techniques used are Conten analysis (content analysis). The results of the research in the folklore of the people to be obtained as a king of twelve values of religious character, honest, discipline, hard work, creative, independent, curiosity, achievement, responsibility, love peace, environmental care, social care, and friendly/communicative.
\end{abstract}

Keywords: Folklore of the fatherless king, character value.

\section{Pendahuluan}

Pendidikan mempunyai peranan penting dalam kehidupan manusia karena pendidikan merupakan proses pengubahan sikap dan tingkah laku seseorang atau kelompok orang dalam usaha mendewasakan manusia melalui upaya pembelajaran dan pelatihan. Keadaan suatu bangsa dipengaruhi kondisi sumber daya manusia yang ada dalam bangsa tersebut. Pendidikan nasional berfungsi mengembangkan kemampuan kecerdasan kehidupan bangsa sesuai dengan UU Nomor 20 Tahun 2003 menyatakan bahwa pendidikan nasional berfungsi mengembangkan kemampuan dan membentuk watak serta peradaban bangsa.

Dalam prosesnya dapat diketahui bahwa pendidikan di Indonesia tidak hanya bertujuan untuk membentuk bangsa Indonesia yang cerdas melainkan juga memiliki kepribadian yang baik. Pembentukan karakter merupakan tujuan dari pendidikan nasional yang wajib dilaksanakan pada jenjang pendidikan untuk membangun karakter siswa. Menurut Samrin (2016) karakter adalah nilai-nilai perilaku manusia yang luas, mencakup hubungan manusia dengan Tuhan, alam, dan sesamanya. Karakter dapat terwujudkan melalui pikiran, perkataan, sikap dan perbuatan.

Namun kenyataan terjadi kemerosotan nilai-nilai karakter pada siswa dipengaruhi oleh masuknya budaya asing dari luar yang memberi perubahan dalam 
kehidupan, perubahan yang terjadi lebih banyak mengarah pada krisis moral. Menurut Wijarnati, dkk., (2019) adapun akibat kurangnya pendidikan karakter antaralain bullying, sopan santu siswa yang menurun, kuranngnya sikap sosial kepada temannya, kuarngnya karakter peduli lingkungan, gemar membaca dan lainnya. Untuk memperbaiki moral dan akhlak anak bangsa diperlukan pendidikan karakter. Sebagaimana yang dikemukakan oleh Syarif, dkk (2016) bahwa banyak pihak yang menuntut peningkatan kualitas pelaksanaan pendidikan karakter di lembaga sekolah formal karena banyaknya fenomena yang berkembang yaitu perkelahian masal dan kurangnya nilai karakter, sehingga pendidikan karakter diperlukan dalam menjawab segala permasalahan yang terdapat di Indonesia.

Menurut kurniawan (2012: 39) pendidikan karakter adalah untuk mengembangkan nilai-nilai yang berasal dari falsafauh atau ideologi bangsa Indonesia, agama, nilai-nilai yang terdapat dalam tujuan pendidikan nasional dan budaya. Budaya menjadi bagian yang penting dalam masyarakat karena mempunyai sumber nilai dalam pendidikan karakter bangsa. Salah satu media yang dapat dijadikan sebagai pembelajaran pendidikan karakter yang sudah menjadi budaya di indonesia adalah cerita rakyat.

Cerita rakyat adalah sebagai contoh kehidupan yang memiliki nilai-nilai karkter. Menurut Gusal (2015) cerita rakyat adalah sebagai gambaran kehidupan tentunya memiliki-nilai-nilai dan norma yang ada dalam masyarakat yang bersifat mendidik. Jadi cerita rakyat merupakan budaya yang mempunyai bermacam-macam nilai karakter yang bermanfaat bagi pembaca.

Dalam menanmkan suatu kebiasan yang baik bagi siswa dapat membentuk sikap, dan perilaku. Pemanfaatan cerita rakyat sangant efektif dalam mengajarkan etika dan moral. Menurut Kristianto (2014) cerita rakyat adalah sarana hiburan yang memiliki suatu ajaran yang bersifat mendidik sehingga dapat dijadikan sebagai media untuk diceritakan kepada anak. Dalam cerita rakyat dapat disampaikan sikap, perilaku maupun tutur kata pada tokoh yang mencerminkan karakter, religius, jujur, disiplin, kreatif dan lainnya. penjelasan di atas yang melatar belakangi peneliti untuk melakukan penelitian terhadap cerita rakyat. Maka peneliti memberi judul "Analisis Nilai-Nilai Karakter Dalam Buku Cerita Rakyat Sang Piatu Menjadi Raja Dari Daerah Bengkulu.

Berdasarkan rumusan masalah di atas, maka tujuan yang ingin di capai dalam penelitian ini yaitu mengetahui dan menganalisis nilai karakter apa saja yang terdapat di dalam buku cerita rakyat sang piatu menjadi raja dari daerah Bengkulu.

\section{Metode}

Jenis penelitian yang digunakan adalah penelitian kualitatif. Penggnaan metode yang dalam penelitian ini adalah deskriptif analisis. Dalam proses menganalisis nilai karakter yang terdapat di dalam cerita rakyat. Penelitian ini menggunakan instrumen tabel analisis. Studi pustaka adalah teknik pengumpulan data yang digunakan dalam penelitian ini. Analisis yang digunakan teknik Conten analisys. Dalam penelitian ini data primer yang digunakan oleh peneliti yaitu buku cerita rakyat, untuk mendapatkan data primer pada penelitian ini peneliti mengumpulkannya secara langsung melalui membaca cerita rakyat, setelah itu peneliti menganalisis nilai karakternya. Pada penelitian ini peneliti tidak menggunakan data sekunder karena data yang ada dalam penelitian peneliti mengumpulkannya secara langsung. Sumber data dalam penelitian ini adalah buku cerita rakyat yang berjudul "Sang Piatu Menjadi Raja". Jenis sumber data dalam penelitian ini adalah dokumen atau arsip berupa Cerita rakyat dari daerah Bengkulu, berbentuk buku yang diperoleh dari Kementrian dan Kebudayaan.

\section{Hasil}

Berdasarkan Analisis nilai-nilai Karakter pada buku cerita rakyat yang berjudul Sang Piatu Menjadi Raja, diperoleh sebanyak tiga belas nilai karakter yang muncul. Adapun tiga belas nilai karakter yang di temukan dalam analisis tersebut 
yaitu: Religius, jujur, mandiri, rasa ingin tahu, kreatif, kerja keras, peduli sosial, disiplin, cinta damai, menghargai prestasi, peduli lingkungan, dan tanggung jawab.

\section{a. Nilai Religius}

Nilai Religius muncul pada cerita rakyat Sang Piatu Menjadi Raja. Peneliti menafsirkan nilai religius pada cerita Sang Piatu Menjadi Raja berdasarkan kutipan kalimat dan kalimat yang terdapat dalam cerita. Dalam cerita Sang Piatu Menjadi Raja nilai religius muncul pada tokoh Sang Piatu, Nenek, dan Raja Mulia

Karakter religius, sesuai indikator patuh terhadap ajaran agama dan melaksanakan ajaran agama yang dianutnya.

\section{b. Nilai Jujur}

Nilai Jujur muncul pada cerita Sang Piatu Menjadi Raja. Peneliti menafsirkan nilai Jujur pada cerita Sang Piatu Menjadi Raja berdasarkan kutipan kalimat dan kalimat yang terdapat dalam cerita. Dalam cerita Sang Piatu Menjadi Raja, nilai Jujur yang muncul pada tokoh Sang Piatu. Karakter jujur Sang Piatu dapat dilihat saat Sang Piatu mengungkapkan keinginannya untuk belajar mengaji ke rumah Raja Mulia. Sesuai dengan indikator kesesuaian ucapan antara yang lahir dan yang batin.

\section{c. Nilai Mandiri}

Nilai mandiri muncul pada cerita Sang Piatu Menjadi Raja. Peneliti menafsirkan nilai mandiri pada cerita Sang Piatu Menjadi Raja berdasarkan kutipan kalimat dan kalimat yang terdapat dalam cerita. Dalam cerita Sang Piatu Menjadi Raja, nilai mandiri yang muncul pada tokoh Sang Piatu. Karakter mandiri Sang Piatu tergambar ketika ia melakukan pekerjaan sendiri. Sesuai dengan indikator mandiri yaitu bertanggung jawab pada diri sendiri secara konsekuen dan tidak tergantung pada orang lain.

\section{d. Nilai Rasa Ingin Tahu}

Nilai rasa ingin tahu muncul pada cerita Sang Piatu Menjadi Raja. Peneliti menafsirkan nilai-nilai rasa ingin tahu pada cerita Sang Piatu Menjadi Raja berdasarkan kutipan kalimat dan kalimat yang terdapat dalam cerita Sang Piatu Menjadi Raja, nilai rasa ingin tahu terdapat pada tokoh Sang Piatu, Nenek, Raja Mulia, Ibu dan Seseorang. Sesuai dengan indikator rasa ingin tahu adalah mengajukan pertanyaan.

\section{e. Nilai Kreatif}

Nilai Kreatif muncul pada cerita Sang Piatu Menjadi Raja. Peneliti menafsirkan nilai kreatif pada cerita Sang Piatu Menjadi Raja berdasarkan kutipan kalimat dan kalimat yang terdapat dalam cerita. Dalam cerita Sang Piatu Menjadi Raja, nilai kreatif yang muncul pada tokoh Sang Piatu saat Sang Piatu membuat tali dari pohon-pohon, bambu-bambu untuk mengikat baling-baling, membuat tempat jualan, membuat tempat menyiram tanaman, sedangkan Raja mulia mengeluarkan ide kreatif dalam pemecahan masalah. Sesuai dengan indikator Kreatif yaitu Mempunyai imajinasi yang tinggi, ulet dan tekun serta berani menyampaikan pendapatnya kepada orang lain.

\section{f. Nilai Kerja Keras}

Nilai Kerja Keras muncul pada cerita Sang Piatu Menjadi Raja. Peneliti menafsirkan nilai Kerja Keras pada cerita Sang Piatu berdasarkan kutipan kalimat dan kalimat yang terdapat dalam cerita. Dalam cerita Sang Piatu Menjadi Raja, tokoh yang terlihat memiliki nilai kerja keras yaitu Sang Piatu. Karakter kerja keras Sang Piatu saat berusaha berkerja keras berkebun dan berjualan keliling, saat berjualan keliling berbagai kata-kata yang membangkitkan semangat, walaupun kata-kata itu ia karang sendiri, demi memberi semangat pada dirinya sendiri. berdasarkan 
indikator selalu mengerjakan tugas, kemudian melakukannya tanpa disuruh atau dikontrol oleh orang lain.

\section{g. Nilai Peduli Sosial}

Nilai Peduli Sosial muncul pada cerita Sang Piatu Menjadi Raja. Peneliti menafsirkan nilai peduli sosial pada cerita Sang Piatu Menjadi Raja berdasarkan kutipan kalimat dan kalimat yang terdapat dalam cerita. Dalam cerita Sang Piatu Menjadi Raja, nilai peduli sosial yang muncul pada tokoh Sang Piatu dan Paman. Indikator peduli sosial yang sesuai yaitu menunjukkan sikap dan perilaku peduli terhadap kepentingan umum dan Memberikan bantuan kepada orang yang membutuhkan.

\section{h. Nilai Disiplin}

Nilai disiplin muncul pada cerita Sang Piatu Menjadi Raja. Peneliti menafsirkan nilai disiplin pada cerita Sang Piatu Menjadi Raja berdasarkan kutipan kalimat dan kalimat yang terdapat dalam cerita. Dalam cerita Sang Piatu Menjadi Raja nilai disiplin muncul pada tokoh Sang Piatu. Nilai disiplin sesuai dengan indikator membiasakan untuk belajar setiap hari.

\section{i. Cinta Damai}

Nilai cinta damai muncul pada cerita Sang Piatu Menjadi Raja. Peneliti menafsirkan nilai cinta damai pada cerita Sang Piatu Menjadi Raja berdasarkan kutipan kalimat dan kalimat yang terdapat dalam cerita. Dalam cerita Sang Piatu Menjadi Raja, nilai cinta damai yang muncul pada Sang Piatu terlihat pada ia menyayangi keluarga dan pegawanya. Nilai cinta damai sesuai dengan indikator perilaku yang penuh kasih dan sayang keluarga maupun sesama.

\section{j. Menghargai Prestasi}

Nilai menghargai prestasi muncul pada cerita Sang Piatu Menjadi Raja. Peneliti menafsirkan nilai menghargai prestasi pada cerita Sang Piatu Menjadi Raja berdasarkan kutipan kalimat dan kalimat yang terdapat dalam cerita. Dalam cerita Sang Piatu Menjadi Raja, nilai menghargai prestasi yang muncul pada tokoh Nenek, Raja Mulia dan Seseorang. Karakter menghargai prestasi Nenek terlihat saat ia mengapresiasi hasil hafalan Sang Piatu dan ikut membantu dengan memperbolehkan untuk belajar sholat dan mengaji. Karakter nilai menghargai prestasi Raja Mulia muncul saat memberikan apresisasi terhadap Sang Piatu, begitupun Seseorang memberikan apresiasi terhadap pencapaian Sang Piatu atas kerja kerasnya. Indikator yang sesuai yaitu memberikan apresiasi terhadap prestasi yang di capai orang lain.

\section{k. Nilai Bersahabat/Komunikatif}

Nilai bersahabat/komunikatif muncul pada cerita Sang Piatu Menjadi Raja. Peneliti menafsirkan nilai bersahabat/komunikatif pada cerita Sang Piatu Menjadi Raja berdasarkan kutipan kalimat dan kalimat yang terdapat dalam cerita. Dalam cerita Sang Piatu Menjadi Raja, nilai bersahabat/komunikatif muncul pada tokoh Sang Piatu dan Raja Mulia. Berdasarkan indikator berbicara dan berkerja sama serta senang belajar dengan orang lain.

\section{Peduli Lingkungan}

Nilai peduli lingkungan muncul pada cerita Sang Piatu Menjadi Raja. Peneliti menafsirkan nilai peduli lingkungan pada cerita Sang Piatu Menjadi Raja berdasarkan kutipan kalimat dan kalimat yang terdapat dalam cerita. Dalam cerita Sang Piatu Menjadi Raja, nilai peduli lingkungan yang muncul pada tokoh Sang Piatu. Karakter peduli lingkungan Sang Piatu tergambar saat ia menyiram tanaman di musim kemarau. Sesuai dengan indikator menjaga dan merawat tanaman. 


\section{m. Nilai Tanggung Jawab}

Nilai Tanggung Jawab muncul pada cerita Sang Piatu Menjadi Raja. Peneliti menafsirkan nilai Tanggung Jawab pada cerita Sang Piatu Menjadi Raja berdasarkan kutipan kalimat dan kalimat yang terdapat dalam cerita. Dalam cerita Sang Piatu Menjadi Raja, nilai Tanggung Jawab yang muncul pada tokoh Sang Piatu melalui tindakannya yang telah menyelesaikan pekerjaannya dengan baik. Sesuai dengan indikator tanggung jawab yaitu melakukan pekerjaan sebaik mungkin.

\section{Pembahasan}

Berdasarkan analisis teks tentang nilai karakter yang terdapat pada buku cerita rakyat, yaitu : Sang Piatu Menjadi Raja, dapat disimpulkan bahwa dari delapan belas nilai karakter yang di analisis dalam cerita tersebut, mengandung tiga belas nilai karakter, yaitu: religius, jujur, mandiri, rasa ingin tahu, kerja keras, kreatif, peduli sosial, disiplin, cinta damai, menghargai prestasi, bersahabat/komunikatif, peduli lingkungan, tanggung jawab. Nilai tersebut muncul atau tampak secara tersurat dan tersirat dalam setiap tokoh serta kutipan dalam cerita.

Nilai Religius perilaku yang taat pada ajaran agama yang dianutnya. Menurut Yaumi (2016: 85) nilai religius merupakan suatu hal yang patuh dalam melaksanakan ibadah bagi agama yang dianutnya dan toleransi terhadap pelakanaan ibadah agama lain, serta hidup secara rukun dengan pemeluk agama lain.

Nilai jujur adalah mengucapkan atau menyatakan hal yang sebnarnya. Menurut Kusuma (2013: 16) jujur adalah adanya kesamaan antara relita dengan ucapan dengan kata lain apa adanya, sesuatu dapat dikatakan jujur apabila sesuai dengan keadaan sebenarnya.

Nilai Mandiri adalah sikap yang tidak bergantung orang lain. Menurut Kurniawan (2013: 143) mandiri adalah suatu sikap dan perilaku yang tidak mudah tergantung pada orang lain dalam menyelesaikan tugas-tugasnya.

Nilai Rasa Ingin Tahu adalah sikap dan tindakan ingin tahu segala sesuatu terhadap hal yang aru. Menurut Yaumi (2016: 102) rasa ingin tahu adalah suatu kemauan untuk mencari tahu tentang yang terjadi atau kata lain penasaran denga sesuatu.

Nilai kreatif adalah sikap yang mampu menciptakan sesuatu yang baru. Menurut samani (2012: 51) kereatif itu adalah sikap yangmampu menyelesaikan masalah secara inovatif, luwes, kritis, berani mengambil keputusan dengan cepat dan tepat.

Nilai kerja keras adalah sikap yang sungguh-sungguh dalam melakukan suatu pekerjaan. Menurut Gunamawan (2012: 33) kerja keras adalah suatu sikap yang menunjukan sebagai upaya mengerjakan pekerjaan dengan sungguh-sungguh.

Nilai peduli sosial sikap seseorang yang peduli terhadap orang lain yang ada disekitarnya. Menurut Listiyarti (2012: 51) peduli sosial adalah memperlakukan orang lain dengan sopan dan santun, serta menghargai dan membantu orang lain.

Nilai menghargai prestasi adalah perilaku menghargai hasil yang telah dicapai oleh diri sendiri maupun orang lain. Menurut Kurniawan (2013: 41) menghargai prestasi adalah sikap dan tindakan untuk mendorong dirinya dalam mengasilkan sesuatu yang berguna bagi orang lain dan mengapresiasi keberhasilan orang lain.

Nilai disiplin adalah sikap seseorang yang patuh terhadap peraturan-peraturan yang ada. Menurut Surya (2010: 46) disiplin adalah tindakan yang dilakukan sesuai dengan ketentuan yang berlaku atau melakukan sesuatu yang sesuai dengan norma yang berlaku.

Nilai cinta damai adalah perilaku seseorang yang menyukai ketenangan hidup bersama. Menurut Yaumi (2016: 108) cinta damai adalah mereka yang menghindari konflik. Tan pa kekerasan dan menegdepankan harmoni, saling menghargai dan relasi yang setara antara individu dan komunitas. 
Nilai bersahabat komunikatif adalah sikap yang menunjukan rasa senang bergaul dengan orang lain. Menurut Yaumi (2016: 107) bersahabat atau komunikatif adalah karakter yang dapat mengantarkan seseorang untuk membangun hubugan baik antara suku, ras, agama dan asal daerah.

Nilai peduli lingkungan adalah suatu bentuk sikap seseorang atau kesadaran terhadap lingkungan disekitarnya. Menurut listiyarti (2012: 7) sikap dan tindakan yang selalu berupaya menjaga kerusakan pada lingkungan di sekitarnya dan upayaupaya untuk memperbaiki kerusakan sekitarnya.

Nilai tanggung jawab adalah seseorang terhadap apa yang seharusnya menjadi kewajiban yang dikerjakan. Menurut yaumi (2016: 114) tanggung jawab adalah sesuatu yang harus dilakukan dalam memenuhi kewajiban terhadap suatu pekerjaan yang diamanahkan.

\section{Simpulan}

Berdasarkan analisis teks tentang nilai karakter yang terdapat dalam cerita rakyat, yaitu : Sang Piatu Menjadi Raja, dapat disimpulkan bahwa dari delapan belas nilai karakter yang di analisis dalam cerita rakyat tersebut, mengandung tiga belas nilai karakter, yaitu: religius, jujur, mandiri, rasa ingin tahu, kerja keras, peduli sosial, kreatif, disiplin, menghargai prestasi, bersahabat/komunikatif, cinta damai, peduli lingkungan, dan tanggung jawab. Nilai tersebut muncul atau tampak secara tersurat dan tersirat dalam setiap tokoh serta kutipan dalam cerita.

Dari hasil analisis kedua judul cerita rakyat tersebut, banyak terkandung nilai-nilai karakter yang ada pada cerita, sehingga bacaan tersebut dapat menumbuhkan nilai-nilai karakter pada siswa yang membaca Sang Piatu Menjadi Raja.

\section{Saran}

Berdasarkan hasil penelitian yang dilakukan, maka peneliti menyampaikan beberapa saran sebagai berikut.

1. Peneliti berharap dapat menjadi refernsi untuk menjadi bacaan bagi siswa terutama kelas tinggi.

2. Peneliti berharap untuk peneliti sleanjutnya dapat menganalisis buku yang memuat karakter yang belum terdapat pada penelitian ini

\section{Referensi}

Arikunto, Suharsimi. 2014. Prosedur Penelitian Suatu Pendekatan Praktis. Jakarta: PT. Rineka Cipts

Gunawan, Heri.2012. pendidikan karakter konsep dan implementasi. Bandung: Penerbit Alfabeta

Hasnunidah, Neni. (2017). Metodologi Penelitian Pendidikan. Yogyakarta: Media Akademi.

Isnawati, Esti.2011. Metode Penelitian Pendidikan Bahasa Dan Sastra. Surakarta: Yuma Pustaka

Kementrian Pendidikan Nasional. (2010). Pengembangan Pendidikan Budaya dan Karakter Bangsa.

Kementrian Pendidikan Nasional. (2011). Pedoman Pelaksanaan Pendidikan Karakter.

Kurniawan, syamsul. 2013. Pendidikan Karakter Konsepsi Dan Implementasinya Secara Terpadu Di Lingkungan Keluarga, Sekolah, Perguruan Tinggi, Dan Masyarakat. Yogyakarta: Ar-Ruzz Media

Listyarti, Retno. (2012). Pendidikan Karakter dalam Metode Aktif, Inovatif, dan Kreatif. Erlangga: gapprint

Winarni, E.W.2018. Teori dan Praktik Penelitian Kuantitatif, Kualittif,PTK Resreach and Development. Jakarta : Bumi Aksara. 
Apriani, Wurjinem., Kustianti, S. K.

Yaumi, Muhammad. 2016. Pendidikan Karakter Landasan, Pilar Dan Implementasi.

Sumber Lain :

Jakarta: Prenamedia Group

Gusal, La Ode. (2015) Nilai-Nilai Pendidikan Karakter Dalam Cerita Rakyat Sulawesi Tenggara Karya La Ode Sidu. Jurnal Humnaika. No. 15, Vol. 3.

http://ojs.uho.ac.id/index.php/HUMANIKA/article/viewFile/611/pdf

(Di unduh pada tanggal 02 Juni 2020)

Hartati, Welly. (2017). Implementasi Pendidikan Karakter Disiplin Di SD Negeri 7 Tanjung Jaya. Jurnal Manajemen, Kepemimpinan, dan Supervisi Pendidikan. Vol. 2, No. 2.

file://C:/Users/R30-C/Downloads/230894-implementasi-pendidikan-karakter-disipli49f4c2f9.pdf 